\title{
Configuraciones místicas de la imaginación en la obra poética de Aurelio Arturo
}

\author{
María Ignacia Schulz ${ }^{1}$ \\ Universidad de Cartagena
}

\section{Resumen}

El presente ensayo pretende mostrar que la reiteración de imágenes y de temas en la poesía de Aurelio Arturo está sostenida por el entramado simbólico que configuran las Estructuras Místicas de lo Imaginario, el Esquema del Descenso y los arquetipos de la Morada, de la Madre y de la Noche. Insertándose su obra así en la dinámica propia del Régimen Nocturno de la Imagen. El artículo presenta un análisis de los símbolos recurrentes, describiendo el modo cómo son reelaborados por el hablante lírico. Para el análisis se siguen los lineamientos teóricos establecidos por Gilbert Durand en su obra Las Estructuras Antropológicas de lo Imaginario (1979/ 1981).

\section{Abstract}

The present essay tries to show that the iteration of images and topics in Aurelio Arturo's poetry is supported by the symbolic framework of the Mystical Structures of the Imaginary, the Schema of Descent and the archetypes of the Dwelling, the Mother and the Night. Therefore it can be included in the proper dynamic of the Nocturnal Order. The article presents an analysis of the recurrent symbols describing the way how they are re-elaborated by the lyric speaker. The analysis follows the theoretical guidelines established by Gilbert Durand in his work The Anthropological Structures of the Imaginary (1979/ 1981).

\footnotetext{
${ }^{1}$ Profesional en Lingüística y Literatura, Facultad de Ciencias Humanas, Universidad de Cartagena. Actualmente se desempeña como Coordinadora del Área de Español en los portales de lengua www.spanisch-lehrbuch.de y www.deutsch-lehrbuch.de. Textos suyos han aparecido en la Revista Sociocultural Bilingue Café Latino y en el boletín digital (español-francés) Rancho Aparte. Este artículo es una versión resumida del trabajo de grado "Configuraciones místicas de la imaginación en la obra poética de Aurelio Arturo”, Cartagena, 1999. Correo-e: angeldelluvia@yahoo.com.
} 
Palabras clave: configuraciones místicas, imaginario, infancia, Durand.
Key words: mystical configurations, imaginary, childhood, Durand.

\section{Introducción}

La obra poética del nariñense Aurelio Arturo (1906-1947) no sobrepasa los cuarenta poemas, y éstos, aunque escritos en épocas distintas, muestran una notoria unidad en las imágenes y en los temas que recrean ${ }^{2}$. En su poesía diversos comentaristas han observado la presencia del paisaje americano: la identificación tierra-mujer, amada-tierra; la nostalgia, el pasado-infancia; el onirismo ${ }^{3}$.

Teniendo en cuenta la temática arriba enumerada, este ensayo desarrolla la hipótesis de que en la poética de Aurelio Arturo la reiteración de temas y de imágenes está sostenida por el entramado simbólico que van configurando las estructuras místicas de lo imaginario ${ }^{4}$, el esquema del descenso y los arquetipos de la morada, de la madre y de la noche -isomorfos y mutuamente conducentes-. Por lo tanto, sostenemos que la obra poética del nariñense se halla anclada en la dinámica propia del régimen nocturno de la imagen expuesto por Gilbert Durand (1981), en quien nos apoyaremos teóricamente. De manera complementaria, para el desarrollo de la primera parte, tendremos en cuenta las reflexiones de Gastón Bachelard (1993) acerca de las ensoñaciones del espacio feliz.

El régimen nocturno se caracteriza por eufemizar o transmutar los valores negativos de los rostros terroríficos del tiempo, por erigirse sobre las dominantes digestiva y sexual y por constelar los símbolos de la inversión y de la intimidad, orientado inicialmente bajo el esquema del descenso, hacia un "complejo de retorno a la gran madre" a través de imágenes como la casa, la noche, el elemento telúrico y la instauración del tiempo mítico ${ }^{5}$.

2 Para mayores datos biográficos, véase Ávila \& Garzón. (1977); Cadena Silva (1991). Los poemas que integrarán Morada al Sur serán publicados entre 1931 y 1960 (Camacho, 1977).

${ }^{3}$ Presencia del paisaje americano: Arbeláez (1986); identificación tierra-mujer, amada-tierra: Camacho (1990); nostalgia, pasado-infancia: Ospina (1986), Arango. (1992), Alvarado Tenorio (1994); el onirismo: Duque (1996) y, O`Hara (1987).

${ }^{4}$ Para Gilbert Durand, el adjetivo místico conjuga al tiempo una voluntad de unión como cierto gusto por la intimidad secreta.

${ }^{5} \mathrm{~A}$ la actitud imaginaria nocturna va a oponerse casi punto por punto una diurna, conformada por tres grandes esquemas: el ascensional, el espectacular y el diairético. El "régimen diurno de la imagen" se complace en lo racional, en la antítesis 
Este régimen funciona por medio de cuatro estructuras de lo imaginario que Durand denomina místicas: reduplicación, viscosidad, realismo sensorial y gulliverización, las cuales constituyen procedimientos operativos de la psiquis para amalgamar las imágenes nocturnas. Estas estructuras las veremos en acción en la poética arturiana, a la luz de los arquetipos ya mencionados y de otros símbolos caracterizadores del "régimen nocturno de la imagen".

\section{Descendiendo}

"Y al acordarnos de las 'casas', de los 'cuartos' aprendemos a 'morar' en nosotros mismos".

Gastón Bachelard, La poética del espacio.

La casa, como lo señala Bachelard, es nuestro rincón del mundo, nuestro primer universo. En ella, el recuerdo de bienestares pasados toma presencia; es el espacio donde hemos sufrido, deseado, amado, que no queremos borrar, aunque ya no exista. Perenne y salvaguardado por el cariño que le tuvimos, volveremos a él a través del sueño o del recuerdo, al lugar ahora perfecto por medio de la ensoñación: cálido y fresco, pequeño y grande, al fin, consolador (Bachelard, 1993). Esta es la imagen de la casa a la cual Aurelio Arturo desciende a través de la palabra que instaura el poema (descenso que puede ser directamente evocado como mediado por la noche, o descenso que aloja un tiempo mítico $)^{6}$ :

Y aquí principia, en este torso de árbol, en este umbral pulido por tantos pasos muertos, la casa grande entre sus frescos ramos.

En sus rincones ángeles de sombra y de secreto.

En esas cámaras yo vi la faz de la luz pura.

Pero cuando las sombras las poblaban de musgos, allí, mimosa y cauta, ponía entre mis manos, sus lunas mas hermosas la noche de la fábulas. ("Morada al Sur II", 8)7

polémica. Puede decirse que todo él está pensado "contra" las tinieblas, la caída y la animalidad. Ambos regímenes se hallan establecidos sobre gestos dominantes o disposiciones de tipo biológico que constituyen el punto de partida de ciertos comportamientos psíquicos, de ciertas imágenes básicas de los esquemas. Así, el régimen diurno estará estructurado por la dominante postural y sus implicaciones manuales y visuales (Durand, 1981: 115 y ss).

${ }^{6}$ Estas tres formas del descenso se penetran constantemente, y al final, constituyen una sola. La separación, muy sutil por cierto, muestra nuestro interés por apreciar en detalle cómo va configurándose el "esquema del descenso".

${ }^{7}$ Entre paréntesis el título del poema. Los datos de la edición trabajada aparecen en la bibliografía bajo Aurelio Arturo (1992). 
El hablante lírico ubica la "casa grande" junto al torso de un árbol. Esta situación discursiva pone en evidencia dos de las formas del funcionamiento psicológico de la imaginación en su particular manera de anexionar las imágenes. En el terreno de la psiquis estamos en presencia de una casa dentro de otra, puesto que el árbol, como la casa, en una de sus valencias simbólicas, es morada ${ }^{8}$. Así, subyacen en este primer verso dos estructuras místicas de lo imaginario: la viscosidad y la reduplicación.

La primera amalgama imágenes que, aunque aparentemente distintas, son isomorfas; marca una tendencia a la unión, a la confusión y al aglutinamiento (árbol/casa); la segunda, gracias a un encajonamiento sucesivo, genera la perseveración y reafirmación de las ideas. En este caso, la facultad de residir ${ }^{9}$, ya que nos encontramos ante una reduplicación de la protección.

Otra imagen que nos conduce a la facultad de habitar de la "casa grande" es la luz que se enciende en sus cámaras: sólo por su luz la casa es humana. Y es esta luminosidad la que permite la disminución del terror, en la medida en que se puede descender con mayor tranquilidad ${ }^{10}$. El miedo que provocaría una oscuridad absoluta sería el resultado del miedo del hombre que torna a las situaciones primitivas de la cueva (Bachelard, 1993: 49 y ss). Ahora el hablante lírico puede descender con confianza y guardar en la casa el valor más sustancial: la evocación de la infancia:

Un largo, un oscuro salón rumoroso cuyos confines parecían perderse en otra edad balsámica.

[...] Un largo, un oscuro salón, tal vez la infancia. ("Canción del ayer", 13).

La casa pertenece a "otra edad balsámica" y el lugar que la define con mayor constancia es el salón "rumoroso", "oscuro", "penumbroso", identificado con la infancia, al que vuelve sus pasos:

Y yo volvía, volvía por los largos recintos

que tardara quince años en recorrer volvía. (“Morada al Sur III", 10).

\footnotetext{
${ }^{8}$ El árbol es imagen del centro bienhechor, es la casa de los pájaros

${ }^{9}$ Aunque pueda parecer obvio, no todas las casas tienen la facultad de habitarse tranquilamente. Esta facultad dependerá de las descripciones confortables que haga la imaginación.

${ }^{10}$ A diferencia de la luz diurna, cuyo resplandor enceguece, la luz nocturna es tenue y rememora una pureza original. De allí que no haya contraposición de sentidos cuando el hablante lírico se regocija también en la penumbra, puesto que la luz que le interesa es aquella apenas insinuada.
} 
Esta identificación suscita la ensoñación de la casa como el espaciotiempo íntimo, secreto, curativo. La presencia del recinto y del salón subrayan la valoración de la misma como "sitio seguro", "protector". Cuando la casa se complica, es decir, tiene sótanos, salones, rincones, "nuestros recuerdos hallan refugios cada vez más caracterizados" (Bachelard, 1993: 38). Y en estos rincones-refugios el hombre encierra o disimula sus secretos: "En sus rincones ángeles de sombra y de secreto" (Arturo, 1992: 8). El rincón es un refugio que, además, nos asegura la quietud, la inmovilidad.

La imaginación ha encontrado así un albergue, un lugar donde habitar; por eso construye muros, visibles o no, palpables o no, pero que garanticen la protección, seguridad e intimidad requerida:

En esas cámaras yo vi la faz de la luz pura

pero cuando las sombras las poblaban de musgos

[...] Entre años, entre árboles, circuida

Casa grande, blanco muro, piedra y ricas maderas. (“Morada al Sur II”, 8).

Siendo ahora posible el ensueño y la evocación, la nostalgia y el recuerdo, el descenso y el retorno, se necesitarán entonces protecciones que, además, sacralicen. Para Durand, lo que sacraliza un lugar es, ante todo, su cierre: islas de simbolismo amniótico, o también bosque cuyo horizonte se cierra en sí mismo. El bosque es centro de intimidad, como puede serlo la casa, la gruta o la catedral. El paisaje cerrado de la selva es constitutivo del lugar sagrado. Todo lugar sagrado comienza por el bosque sagrado (Durand, 1981: 234).

La casa grande de Arturo estará cerrada, circuida, por el "viejo bosque", las "sombras", "los años", "el blanco muro", "la noche de brisas del bosque". Estos elementos separan el mundo externo fuera de la casa y del bosque- del interno -dentro de la casa o en el bosque ${ }^{11}-$, a la vez que introducen una diferenciación-oposición entre el tiempo presente no maravilloso y el tiempo de la infancia:

Esta es la canción del niño que soñaba caminando por el salón penumbroso de brisa lenta que estremecía sus pequeñas alas, y oía, afuera, entre los árboles las arpas de la noche, y voces ¿por qué tantas voces en el silencio?

(“Canción del niño que soñaba", 48).

\footnotetext{
${ }^{11}$ Acerca de esta idea, véase en especial el capítulo "La dialéctica de lo de dentro y de lo fuera". (Bachelard, 1993: 250-270).
} 
Y si al norte el viejo bosque tiene un tic-tac profundo al sur el curvo viento trae franjas de aromas. ("Morada al Sur II", 8).

Estar dentro de la casa o en el bosque no genera angustia: la penumbra y la música tranquilizan la imaginación. La marca temporal que introduce el tic-tac es limada por el adjetivo "profundo" que nos conduce a la idea de lo íntimo. En suma, en Arturo el bosque es una prolongación de la morada.

La sensación de seguridad y de intimidad que nos ha dejado percibir el hablante lírico se debe a la puesta en funcionamiento ahora de las estructuras místicas de la reduplicación y la gulliverización o miniaturización. La primera genera una perseveración de las imágenes: la intimidad que suscita la casa será el resultado de una resistencia a salir de las imágenes familiares y confortables: los salones, los recintos, el armario, la música, etc. A nivel del lenguaje podemos apreciarla en la frecuencia de figuras sinestésicas, metafóricas y paradójicas. Formando imágenes que aunque distintas, tienen descripciones comunes, produciendo de este modo las respectivas asociaciones simbólicas ${ }^{12}$. Resultando así la perseveración: "sombras brillantes", "noches dulces", "Era tu dulce tierra cantando", "Oíd el canto dulce", “¿Dónde el agua que brilla y canta?”

La estructura de la miniaturización opera de un modo más sutil, gracias a una contención sucesiva de imágenes el valor sustancial se asimila al último contenido, al más pequeño, al más concentrado de los elementos (Durand, 1981: 255 y ss). Así, en las tierras del sur encontramos el bosque. Éste rodea la casa, la cual, a su vez, contiene las cámaras y los recintos que guardan, como el "más concentrado de los elementos", las ensoñaciones de la infancia. La casa física pasa, de alguna manera, a un segundo plano en la poética arturiana para poner de manifiesto la magnificencia del recuerdo. En esta última estructura la forma material ya no importa, sino la sustancia, lo contenido. Por eso la encontramos parcamente descrita. "El excesivo pintoquerismo de una morada puede ocultar su intimidad [...]. Describirlas equivaldría a ¡enseñarlas! [...]. La casa primera y oníricamente definitiva debe conservar su penumbra" (Bachelard, 1993: 43). Y Bachelard luego añade: "Sólo debo decir de la casa de mi infancia lo necesario para ponerme yo mismo en situación onírica,

\footnotetext{
${ }^{12}$ Nos interesa marcar la reduplicación por la frecuencia de las figuras literarias; no obstante, reconocemos que desde otro ángulo puede verse en este caso la presencia de la estructura mística de la viscosidad, dado que en la metáfora, en la sinestesia e incluso en la paradoja hay tanto la unión de elementos semejantes como de campos semánticos distintos. Al final de cuentas, la viscosidad temática, esa tendencia a la unión, es natural al régimen nocturno.
} 
para situarme en el umbral de un ensueño donde voy a descansar de mi pasado" (43).

El mayor beneficio que reporta la casa es el de proteger al soñador: "La vida empieza bien, protegida, toda tibia en el regazo de una casa" (Bachelard, 1993: 37). Existe un isomorfismo, señalado por Durand, entre vientre materno, tumba, cavidad en general y la morada cerrada en su lecho, debido a que comportan características comunes: protección, seguridad, reposo, calma, calor íntimo. De allí que la casa posea rasgos femeninos en cuanto es asimilada a un vientre materno. Dadas sus características de refugio es siempre la imagen de la intimidad descansada. En la poesía de Aurelio Arturo esta imagen se sustenta por la calma, el reposo y la hondura materna que transmite la presencia constante del color verde.

Ya hemos señalado su carácter protector, y Bachelard nos aclara aún más cuando dice:

Cuando se sueña en la casa natal, en la profundidad extrema del ensueño, se participa de este calor primero, de esta materia bien templada del paraíso material. En este ambiente viven los seres protectores. (37-38).

Añadiendo otro elemento: protege también, porque hace surgir a la madre misma, el ser protector por excelencia:

Mas, ¿quién era esa alta, trémula mujer, en el salón profundo?

¿quien la bella criatura en nuestros sueños profusos?

¿quizá la esbelta beldad por quien cantaba nuestra sangre?

¿o así, tan joven, de luz y silencio, nuestra madre?

0 acaso, acaso esa mujer era la misma música, la desnuda música avanzando desde el piano, avanzando por el largo, por el oscuro salón como en un sueño.

(“Canción del ayer", 13).

En suma, la casa, el entorno y los seres protectores configuran una Arcadia (Frenzel, 1980), el lugar que recupera un pasado maravilloso, feliz, seguro, que sólo puede existir por medio de la añoranza y de la nostalgia. Un espacio-tiempo imposible de reinsertar en el tiempo presente.

Acerca de esto último, Graciela Maglia Ferrari (1994) tiene un excelente artículo en donde muestra que la "evasión romántica" que Arturo construye de la infancia, de la "edad balsámica, se rompe al tornarse ineludible la realidad de un tiempo histórico": 
Y hacia la mitad de mi canto me detuve temblando, temblando temeroso, con un pie en un cámara hechizada, y el otro a la orilla del valle donde hierve la noche estrellada, la noche que arde vorazmente en una llama tácita. Y a la mitad del camino de mi canto temblando me detuve, y no tiembla entre sus alas rotas, con cuanta angustia, una ave que agoniza, cual pudo, mi corazón luchando entre cielos atroces. ("Morada al Sur", 10).

Pero antes de producirse este cruce temporal que ocasiona el desmoronamiento del recuerdo de la infancia dichosa, el hablante lírico ha instalado con perfección una arcádica morada. El título del poemario ${ }^{13}$, Morada al Sur, es ya bastante sugestivo. La palabra morada, en su acepción, implica a la vez residir, habitar, y por lo tanto, lugar, como detención, espera, y en consecuencia, tiempo. La especificación al "sur" va cargada también de las dos valencias: a la vez posición geográfica y tiempo anterior, pasado.

Esta morada al sur está inserta en un paisaje bien definido y precisamente nombrado: una "ancha tierra" en donde "el viento viene vestido de follajes" y "el viejo bosque tiene un tic-tac profundo"; llena la tierra de "hermosos caballos", de "noches alumbradas", de ríos y en donde "el verde es de todos los colores".

El culto a la Gran Madre está marcado también por un simbolismo telúrico; la tierra está asociada a la imagen materna en cuanto constituye refugio, alimento y cuna. Por eso este "culto" a la morada, ubicada en las tierras del sur, es una reafirmación del "complejo de retorno a la gran madre". Las tierras del sur edifican, a la vez, la percepción de una tierrahembra:

Tierra buena, murmullo lánguido, caricia, tierra casta, ¿cuál tu nombre, tu nombre tierra mía, tu nombre Herminia, Marta? [...]

Tierra, tierra dulce y suave, ¿Cómo era tu faz, tierra morena? ("Remota luz", 25).

La identificación amada/mujer/tierra ha sido ya observada por diversos comentaristas. El doble aspecto de la tierra, mujer y

${ }^{13}$ Según Danilo Cruz Vélez (1977), el título lo exigió la colección en la que sería publicado el libro, dada la temática común a la mayoría de sus textos. 
madre, es el natural resultado de las fabulaciones de lo imaginario que unen psíquicamente el esquema del descenso y la dominante sexual a la imagen de la tierra. Por mediación de este esquema la tierra es penetrable, confiriéndole el carácter sexual y generando su asociación con la tierra-hembra, con la tierra que es la mujer amada.

[...] yo desperté en un sueño de espigas de oro trémulo

junto al cuerpo núbil de una mujer morena

y dulce, como a la orilla de un valle dormido.

(“Canción de la noche callada", 18).

A su vez, el carácter materno es dado por la imaginación mística, cuya voluntad de unir asocia a la cuna bienhechora con la tierra, ya que ésta es el lugar del último reposo. La separación que hemos establecido obedece a criterios de orden expositivo más que a una propiedad de la fabulación mística, ya que, debido a las cuatro estructuras que componen el imaginario nocturno, la intención permanente es la de amalgamar las imágenes. “¿Era tu dulce tierra cantando, tu carne milagrosa, tu sangre?" ("Morada al Sur IV", 11).

Esta actitud de la imaginación, semejante a la mantenida con la casa es muestra de la persistencia del "complejo de retorno" en la poesía arturiana, y éste, como lo ha indicado Durand, invierte y sobredetermina la valoración de la muerte y del sepulcro, "refleja el isomorfismo del retorno, de la muerte y de la morada" (Durand, 1981: 225): "Torna, torna a esta tierra donde es dulce la vida" ("Morada al Sur IV", 12).

Con esta última asociación simbólica: mujer/amada/tierra se ha completado una primera forma del descenso. El hablante lírico después de haber construido una morada segura e íntima en la que aparecían los seres protectores y en la que podía disimular sus secretos y evocar con tranquilidad un pasado, descendió hasta la profundidad del elemento terrestre, para re-encontrarse con lo que realmente era su destino: la búsqueda de un retorno. La tierra-casamorada se convierte entonces en una nostalgia del retorno ${ }^{14}$, que esconde para la imaginación la eufemización y revalorización de la muerte:

Cabelleras y sueños confundidos

cubren los cuerpos como sordos musgos

en la noche, en la sombra bordadora

\footnotetext{
${ }^{14}$ Insistimos en esta idea, aunque autores como Oscar Torres Duque (1992) no consideren que en la poesía de Arturo haya siquiera un asomo de nostalgia.
} 
de terciopelos hondos y de olvidos [...]

Ronco tambor entre la noche suena

cuando están todos muertos, cuando todos,

en el sueño, en la muerte, callan llenos

de un silencio tan hondo como un grito. ("Silencio", 38).

\section{Paisaje nocturno}

"Mira, mira con ojos puros".

Aurelio Arturo, Morada al Sur y otros poemas.

La noche y su estela de elementos: lunas, sombras, penumbras, música, agua, color, tienen en la poética arturiana valencias semánticas que se tejen y se destejen en un proceso continuo, obedeciendo fielmente a los imperativos psíquicos del régimen nocturno. Encontramos una transmutación de sus valores negativos mediante, primero, una adjetivación positiva: la noche será dulce, estrellada, amorosa, balsámica, tibia, honda, callada. Segundo, por la relación de la noche con los recuerdos vitales de una infancia dichosa. Después estos símbolos se constituirán en imágenes del descenso que desembocarán en la eufemización del vientre materno, subrayando la añoranza de un estadio prenatal. La adjetivación es clara y muestra el isomorfismo existente entre "dulce", "tibia", "balsámica” y "callada”.

La noche se convierte en la poesía de Arturo en la propuesta de un descenso a la sustancia del no-tiempo, al reino mismo de la intimidad del ser (Durand, 1981: 209). Sin embargo, no seguiremos este recorrido, porque opera de manera homóloga al descenso a la morada. Como señalábamos al inicio, los arquetipos de la madre, de la morada y de la noche, son mutuamente conducentes, creando en consecuencia un entretejido simbólico común, sustentado en imágenes de la intimidad y en una particular manera de mirar el mundo: la "mirada infantil" propia de la estructura mística de la gulliverización (miniaturización).

En este segundo apartado nos ocuparemos, en primer lugar, de otros símbolos resonadores de la intimidad como son el color, la melodía y el agua para finalmente analizar la estructura de la miniaturización que es, a nuestro modo de ver, la actitud imaginativa predominante en el hablante lírico.

A diferencia de la "noche diurna", amenazante, tenebrosa, la nocturna se torna tranquila, hermosa, gracias a un proceso de eufemización. 
La presencia del color es indicador de este cambio de valores puesto que es eufemización de las tinieblas impenetrables. Durand nos hace notar que el esquema del descenso se colorea de la densidad nocturna (1981: 212), desplegando la riqueza del prisma. El color, por ser interior preciado, se convierte en cualidad íntima, sustancial; los colores son fondos de sustancia:

\author{
Cántame tus canciones, \\ tus esbeltas, desnudas canciones, \\ esas que se visten de menudas hojas verdes \\ y hojas rojas, \\ y hojas verdidoradas, \\ con cortezas resinosas \\ y pequeñas piedras pulidas por el agua. \\ Cántame tus canciones: \\ las de los delgados cielos azules, \\ de las nubes azules, \\ de las montañas azules. [...] \\ Y la canción de los hermosos caballos, \\ en la que se enumeran los caballos por sus colores, [...] \\ Y la canción de los pájaros, las aves \\ que se nombran según sus plumajes \\ y sus vuelos y sus melodías [...] \\ Y la honda canción de las noches \\ que hablan doradas palabras. (“Canciones", 46).
}

En este poema encontramos que los elementos que definen la naturaleza de "las tierras del sur": hojas, cielos, nubes, montañas, caballos, pájaros y noches, son nombrados a partir del color, un color que les brota desde adentro. Para lograr esta definición el hablante lírico recurre a la "estructura mística del realismo sensorial", es decir, a la vivacidad de las imágenes, vivacidad concreta tanto sensorial como imaginaria de la fantasía mística (Durand, 1981: 255 y ss). Por medio del realismo sensorial se penetra en las cosas, animándolas, revelando su significado íntimo.

Esta estructura también permite que la imaginación recree los símbolos del modo más benéfico para ella. Así, por ejemplo, encontramos que el caballo, asociado al fluir temporal, al paso del tiempo -por su movimiento-, es principalmente nombrado por sus colores, realizándose ante nuestros ojos su eufemización. Pierde el carácter terrorífico como anunciador del transcurso del tiempo histórico. En este sentido, también llama la atención que el pájaro, tan caro a la imaginación diurna, es esencialmente enunciado por sus cualidades cromáticas y melodiosas, más que por la facultad del 
vuelo ${ }^{15}$. La psiquis hace todo lo posible por acomodar a su beneplácito las imágenes que puedan aterrorizarla. La fuerte presencia del color es signo ya de la mirada del niño que evoca:

En estos cielos vivos de las tierras de nadie hay tanto vuelo ágil, tanta pluma irisada, que es como si los pájaros fueran aquí mas libres, que es como si esta tierra fuera tierra de aves.

("Tierras de nadie", 39).

Esta tierra de aves se vuelve entonces una tierra multicolor -no se olvide que el plumaje estará ligado a la imaginación del colorido-. De esta forma, el hablante lírico evidencia su necesidad de vivir en lo concreto, o al menos, de concretizar lo imaginado, para así poder darle vida a sus ensoñaciones. Sentir muy de cerca a los seres y a las cosas es una facultad que provee la estructura mística del realismo sensorial, capacidad de animar y de vivificar.

Al simbolismo del color se une el de la melodía, y ambos no son más que manifestación de las aspiraciones de la psiquis por rehabilitar y exorcizar la sustancia misma del tiempo (Durand, 1981: 212). La melodía es eufemización del ruido: si el bosque es penetrado por armonías sonoras, es porque la dinámica nocturna sabe que de esta forma crea el lugar encantado y renueva a sí mismo la confianza para transitarlo:

Te hablo de un bosque extasiado que existe sólo para el oído, y que en el fondo de las noches pulsa violas, arpas, laúdes y lluvias sempiternas. ("Morada al Sur II", 9).

Y el bosque era sonoro. Y en la atmósfera palpitaba la luz como abeja de ritmo. ("Sol”, 26).

Las sensaciones con-fundidas del sabor y de la audición muestran los procedimientos nocturnos para unir contrarios y anastomosar imágenes. La técnica psíquica que aflora es la de la viscosidad temática, ya que melodía y color están relacionados en el inconsciente, porque ambos eufemizan la duración temporal y son símbolos de la feminidad sustancial: "Oíd el canto dulce de las tierras de nadie/ Tanta belleza es cierta, sensual, sencilla" ("Tierras de nadie", 39).

${ }^{15}$ Para el régimen diurno el pájaro es uno de los símbolos ascensionales por excelencia, hasta el punto de que sólo el ala simboliza la búsqueda de lo Alto. No es extraño encontrar imágenes diurnas en el régimen nocturno, de hecho con frecuencia se encuentran, sólo que sus valores se transmutan o eufemizan como una forma de dominarlas. Al final de cuentas, son estrategias propias de la imaginación para reconfortarse. 
En estos versos encontramos que la descripción es muy femenina, "sensual", lo que tiene su explicación en las connotaciones simbólicas que ya mencionamos. A la tierra se van adhiriendo los adjetivos de "dulce" y de "sensual" gracias a la acción del régimen nocturno de la viscosidad que señala variaciones temáticas o de figuras que, no obstante, ponen de manifiesto el isomorfismo de la interpretación.

Generalmente, en la delectación nocturna de la imaginación vamos a hallar junto a la melodía y el color, el agua. Ésta, que en el régimen diurno tiene el propósito de limpiar, en el nocturno será "vehículo del tinte", ofrecerá en su espejo todos los colores y se irá haciendo más densa: "¿Donde el agua desnuda,/ el agua que brilla y canta?" ("Sequía", 57); "Y unas aguas oscuras que casi no se escuchan" ("Tierras de nadie", 39).

En estaúltima imagen estamos en presencia de un agua prácticamente en reposo. No podemos dejar de notar que el arquetipo de la madre puede estar marcado por un simbolismo telúrico o por uno acuático. Ello significa que, de nuevo, empezamos a transitar por el trayecto psicológico y simbólico que conduce al complejo de retorno a la gran madre. Si el color, la melodía y el agua conducen a una misma interpretación, podemos asegurar, sin lugar a dudas, que las estructuras místicas de lo imaginario están cumpliendo su papel para fijar las imágenes. Pasar tranquilamente de un símbolo a otro subraya la presencia de los procedimientos operativos de la reduplicación, la viscosidad temática y el realismo sensorial funcionando en las fabulaciones de lo imaginario.

Las imágenes, símbolos y arquetipos que hemos ido analizando, además de anexionarse simbólicamente, tienen la característica en común del cómo son miradas, es decir, el hablante lírico construye su percepción del paisaje (morada, tierra, noche, etc.) desde una "mirada infantil" y esta mirada filtra los símbolos que hemos estudiado. La principal característica de esta forma de observar el mundo es una actitud minuciosa, meticulosa; en la búsqueda del detalle se pierde de vista el conjunto:

Te hablo también: entre maderas, entre resinas, entre millares de hojas inquietas, de una sola hoja: pequeña mancha verde, de lozanía, de gracia, hoja sola en que vibran los vientos que corrieron por los bellos países donde el verde es de todos los colores. ("Morada al Sur II", 9). 
En este elemento perceptivo restringido que es "una sola hoja" se integra todo un semantismo más amplio: el intento de condensar, de resumir una realidad que era, a la mirada del niño, inmensa, agigantada, precisamente por él. Podemos recordar nuestra casa natal como un espacio gigantesco, y luego, al pasar los años y retornar, ver cómo nuestra imaginación infantil la sobredimensionó:

Hojas que con marino ritmo ondulaban,

hojas con finas voces

hablando a un mismo tiempo, y que no eran

tántas sino una sola, palpitante

en mil espejos de aire, inacabable.

(“Canción de hojas y de lejanías", 44).

Para este efecto que produce la estructura de la miniaturización podemos hablar de microcosmización, el detalle se vuelve representativo del conjunto y concentra la sustancia misma del universo (Durand, 1981: 264). Pero esta actitud de la imaginación para con la visión del paisaje es natural, ya que éste es siempre microcosmos. Constitucionalmente, el lenguaje no puede aspirar a una similitud de dimensión con el modelo, a una "gigantización del modelo" (Durand, 1981: 265):

Este verde poema, hoja por hoja,

lo mece un viento fértil, suroeste; este poema es un país que sueña, nube de luz y brisa de hojas verdes.

Tumbos del agua, piedras, nubes, hojas, y un soplo ágil en todo, son el canto. ("Clima”, 16).

El afán por la enumeración de elementos del paisaje -o de un elemento-, la preocupación por la figura metafórica, sinestésica y por la personificación tienen como propósito aprehender la naturaleza inmensa "que no se aprehende ni se expresa mas que gulliverizada, reducida -o inducida- a un elemento alusivo que las resume, y de este modo la concentra, la transforma en una sustancia intima" (Durand, 1981: 265):

Mirarás un país turbio entre mis ojos, [...]

Tu desnudez verás en mis ojos absortos, [...]

Por mi canción conocerás mi valle, su hondura en mi sollozo has de medirla.

("Canción de la distancia", 23). 
Reafirmamos, esta peculiar forma de observar, que hemos denominado la "mirada infantil" propia de la miniaturización, permea toda la obra. Así, cada elemento poético es visto desde una mirada que asciende desde la tierra para contemplarlos bajo la grandeza que proporcionan los ojos del niño: "Noche, sombra hasta el fin, entre las secas/ ramas" ("Morada al Sur V", 12).

\section{Reconstrucciones y distancias}

El amplio reconocimiento que día a día recibe la obra de Aurelio Arturo no es gratuito. Maravilla en él su actitud constante por depurar el lenguaje buscando una forma/verso de atrapar la belleza; la vitalidad de sus evocaciones hermosamente nombradas, y no menos importante, su adelantada concepción de la factura del poema. Su obra avanza unos pasos más a la de sus contemporáneos y se acerca, aún más, a las sensibilidades actuales.

Parece ser que en Arturo el signo-clave es la perentoria necesidad por atrapar, o mejor, por reproducir, a través del lenguaje, la armonía y bellezas del universo, y así, reinstaurar el orden de la creación. Su palabra se constituye en una voz analógica ${ }^{16}$ que concibe el mundo como un ritmo y al poema como correspondencia sonora de él:

Juan Gálvez, José Narváez, Pioquinto Sierra, como robles entre robles... Era grato, con vosotros cantar o maldecir, en los bosques abatir avecillas como hojas del cielo. Y Pablo Garcés, Julio Balcázar, los Ulloas, tantos que allí se esforzaban entre los días. Trajimos sin pensarlo el habla de los valles, los ríos, su resbalante rumor abriendo noches, un silencio que picotean los verdes paisajes, un silencio cruzado por un ave delgada como hoja.

("Rapsodia de Saulo", 28).

Por medio de la palabra analógica el hablante también recupera un pasado, un tiempo que en la evocación se torna mítico ${ }^{17}$. Esta doble recuperación que se efectúa deriva en una correspondencia de niveles: por un lado, el universo se vuelve el alojador perfecto del

\footnotetext{
${ }^{16}$ Para la idea de la palabra analógica en Aurelio Arturo hemos partido de las apreciaciones hechas por José Olivio Jiménez (1982).

17 Para Piedad Bonnet (1994), por ejemplo, los elementos de la infancia "son evocados de tal forma, que la experiencia autobiográfica deviene en recreación mítica".
} 
recuerdo perfecto (sostenido en las imágenes de la casa, de la noche y de la tierra), y por otro, el lenguaje en sí mismo se convierte en morada humana.

Los dos niveles señalados se muestran como un encajonamiento reduplicativo en el cual salen fortalecidos el recuerdo infantil y su entorno: casa, noche, bosque. Esta fortaleza sería entonces el producto de las asociaciones simbólicas y literarias derivadas de las estructuras místicas de lo imaginario con sus consiguientes efectos a nivel del lenguaje, de la recuperación analógica del mundo por el poema y de la reiteración arquetípica:

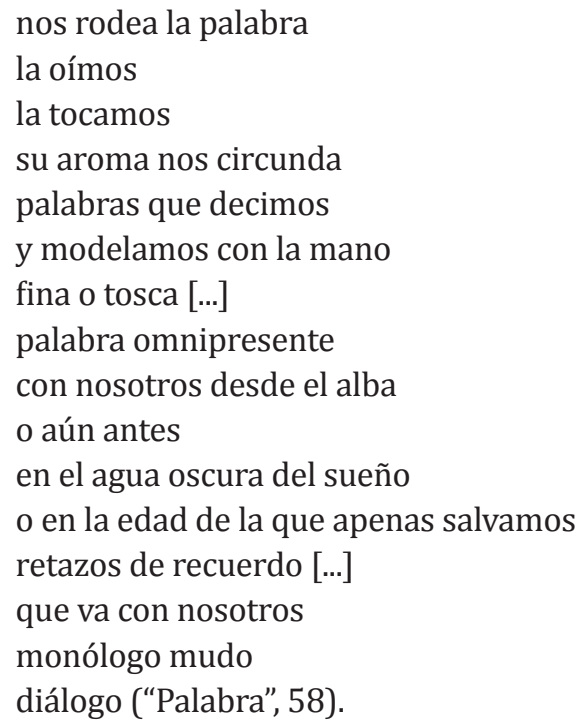

Sin embargo, esta concepción analógica se romperá de un modo sutil, pero inequívoco, al volverse ineludible el paso del tiempo histórico. La conciencia de este paso ya se dejaba presentir cuando la imagen del complejo de retorno y el arquetipo de la noche, nos conducían psíquicamente a la revalorización eufemizada de la muerte. Eufemizar o transmutar el terror que sentimos por el paso del tiempo es una toma de conciencia, aunque sea un distanciamiento crítico de la psiquis. 0 mejor, por ser la psiquis quien lo efectúa, es de mayor relevancia:

Y hacia la mitad de mi canto me detuve temblando, temblando temeroso, con un pie en una cámara hechizada, y el otro a la orilla del valle ("Morada al Sur III", 10).

Existe un poema que creemos de vital importancia para este punto que estamos trabajando, en el cual se transgreden las descripciones 
positivas de la noche campesina, de la noche del recuerdo, a las que nos tenía habituado el hablante lírico, por una revalorización de la noche ruidosa, citadina. Como ya mostramos, la revalorización de la noche conllevaba una revalorización de la muerte. Pero, si la noche valorizada positivamente era la de la infancia, ¿por qué en un único poema ("Yo amo la noche") se desvirtúa su imagen para preferir la noche bulliciosa y cambiar las estrellas naturales por las artificiales que son las lámparas?

No la noche que arrullan las ramas y balsámica con olor de manzanas, con el efluvio de la flor del naranjo; oh, no la noche campesina de piel húmeda y tibia y sana; [...] Yo amo la noche de las ciudades. (54).

Para nosotros el hablante lírico se encuentra distanciado, alejado en el recuerdo. Al saber que es imposible la reconstrucción definitiva y perenne de la Arcadia, de la Morada, desde una actitud de doloroso resentimiento, y de toma de conciencia, señala el flujo temporal, el presente histórico -que ya se cruzaba con sus recuerdos, pero al que trataba de limar con elaboradas eufemizaciones-. La ciudad y sus componentes encierran para la imaginación el movimiento, la prisa, el tiempo de los horarios establecidos y por cumplir. Si la angustia guarda para sí una angustia ante el paso del tiempo, ¿la noche puramente temporal de las ciudades no guarda para sí una conciencia de este paso?

Si bien la temática de la obra de Aurelio Arturo se concentra en la nostalgia de la infancia y en la recreación del paisaje, la dirección semántica y simbólica de las imágenes no es unilateral -como acabamos de apreciar-. La imagen es dinámica y su sentido no puede ser buscado fuera de la significación imaginaria.

\section{Bibliografía}

Alvarado Tenorio, Harold. (20 de noviembre de 1994), "Aurelio Arturo para siempre", en Dominical de El Universal, No. 460, Cartagena.

Arango, José Manuel. (1992). "Aurelio Arturo y la poesía esencial", en Aurelio Arturo. Morada al Sur y otros poemas. Bogotá: Norma (Colección Cara y Cruz).

Arbeláez, Fernando. (1986). "Aurelio Arturo: Morada al Sur", en Aurelio Arturo. Morada al Sur y otros poemas. Bogotá: Procultura.

Aurelio Arturo. (1992). Morada al Sur y otros poemas. Madrid: Ediciones de Cultura Hispánica. Agencia Española de Cooperación Internacional. 
Avila Viviana \& Garzón, Diego Alberto. (mayo-agosto de 1997). "La voz del viento, una bibliografía de Aurelio Arturo" en Gaceta, Bogotá. (Este Artículo reproduce dos capítulos de la primera biografía completa de Aurelio Arturo desarrollada como tesis de grado. Universidad Javeriana, Facultad de Comunicación Social).

Arturo, Aurelio. (28 de agosto de 1994). Magazín Dominical de El Espectador, No. 591(número monográfico), Bogotá.

Bachelard, Gastón. (1993). La poética del espacio. México: Fondo de Cultura Económica (1aㅡ ed. 1957. París: Presses Universitaires de France).

Bonnet, Piedad. (agosto 28, 1994). Magazín Dominical de El Espec-tador, No. 591, Bogotá.

Castillo, Rafael \& Linero, Guillermo. (1997). "Hitos poéticos contemporáneos en Colombia”, en Rostros de la poesía. Poesía colom-biana actual. Bogotá: Cooperativa Editorial del Magisterio.

Cadena Silva, Claudia. (1991). "Aurelio Arturo" en Historia de la Poesía Colombiana Bogotá: Casa Silva.

Camacho, Eduardo. (1977). "Morada al Sur", en Aurelio Arturo. Obra e imagen. Bogotá: Instituto Colombiano de Cultura. Apareció por primera vez en Eco No. 43, Tomo VIII/1; noviembre de 1963.

Cobo Borda, Juan Gustavo. (1977). "Aurelio Arturo: la palabra original", en Aurelio Arturo. Obra e imagen. Bogotá: Instituto Colombiano de Cultura.

Cruz Vélez, Danilo. (1977). "Aurelio Arturo en su Paraíso”, en Aurelio Arturo. Obra e Imagen. Bogotá: Instituto Colombiano de Cultura. Apareció por primera vez en Golpe de Dados (1975), No. 13, vol. III,

Charry Lara, Fernando. (1977). "Aurelio Arturo", en Aurelio Arturo. Obra e Imagen. Bogotá: Instituto Colombiano de Cultura. Apareció por primera vez en Lecturas Dominicales de El Tiempo, diciembre 8 de 1963, Bogotá.

Durand, Gilbert. (1981). Las Estructuras Antropológicas de lo imaginario. Madrid: Taurus.

Echavarría, Rogelio. (1986). "El Aurelio Arturo que yo conocí", en Aurelio Arturo, Morada al Sur y otros poemas. Bogotá: Procultura. Apareció por primera vez en El Tiempo, noviembre 30 de 1975.

Frenzel, Elizabeth. (1980). Diccionario de motivos de literatura universal. Madrid: Gredos.

Lagos, Ramiro. (24 de abril de 1988). “Ciclos de la poesía colombiana”, en Magazín Dominical de El Universal, Cartagena.

Luque Muñoz Henry. (1996). Tambor en la sombra. Poesía colombiana del siglo XX. México: Verdehalgo.

Maglia Ferrari, Graciela. (1994?). "De la nostalgia demorada de la tierra al destierro A-Moroso de la nostalgia”, en Ulrika, No. 23, Bogotá.

Maya, Rafael. (1977). "Aurelio Arturo", en Aurelio Arturo. Obra e imagen. Bogotá: Instituto Colombiano de Cultura. Apareció por primera vez en Crónica Literaria (1931) de El País, Bogotá.

Mutis, Álvaro. (1977). “Mi verdadero encuentro con Aurelio Arturo”, en Aurelio Arturo. Obra e imagen. Bogotá: Instituto Colombiano de Cultura. Apareció por primera vez en Golpe de Dados (1975), No. 13, vol. III. 
O'Hara, Edgar. (1987). “Tres piedras para un cielo", en Boletín Cultural y Bibliográfico (1987), Vol. XXIV, No. 11, Bogotá.

Olivio Jiménez, José. (1982). Antología crítica de la poesía modernista Hispanoamericana. Madrid: Hiperión.

Ospina, William. (1986). "Aurelio Arturo, la Palabra del Hombre”, en Aurelio Arturo. Morada al Sur y otros poemas. Bogotá: Procultura.

Pabón Díaz, Ramiro. (1991). La poética de Aurelio Arturo. El festín de la palabra y de la vida. Pasto: Graficolor.

Tellez, Hernando. (1997), "La poética de Aurelio Arturo", en Aurelio Arturo. Obra e imagen. Bogotá: Instituto Colombiano de Cultura. Apareció por primera vez en El Tiempo, 1964.

Torres Duque, Oscar. (1992). La Poesía como Idilio. Poesía Clásica en Colombia. Bogotá: Colcultura. 
